\title{
Impact of Red Chilli Reference Price Policy in Indonesia
}

\author{
Mirza Sativa*, Harianto, Achmad Suryana \\ Department of Agribusiness, Faculty of Economic and Management, Bogor Agricultural University \\ *Corresponding author E-mail: mizsativa@gmail.com
}

How to Cite: Sativa, M., Harianto., \& Suryana, A. (2017). Impact of Red Chilli Reference Price Policy in Indonesia, Int. J. Agr. Syst. 5(2): 120-139.

\begin{abstract}
Red chilli is one of basic commodities in Indonesia, in household consumption and raw material of industry even though the price of red chilli not only often fluctuates but also contributing to inflation. Policies taken by the government against the red chilli was with the application of the reference price, as the management of importation, for stabilizing the price of red chilli. This study aims to see the effectiveness of the reference price policy in influencing red chilli deals through red chilli import management and determine the factors that affect the red chilli deals in the effort to stabilize the price, using two stage least square (TSLS) simultaneous model with secondary data from Desember 2010September 2016. In this study, red chili supply models in Indonesia consisted of five equations, four structural equations, and one identity equation. The structural equation consisted of red chili production, red chili import, red chili export, and red chili prices while the identity equation namely red chili supply. The results showed that reference price application had not been effective because it was not able to manage the importation properly, caused red chilli prices were still fluctuating. Implementation of reference prices did not significantly affect imports and prices, it indicated that the reference price policy was ineffective. This policy should be pursued by strengthening the development of production and to encourage red chilli farmers interest to increase the amount of production for continuity the supply side.
\end{abstract}

Copyright (C) 2017 IJAS. All rights reserved.

Keywords:

Red chilli; reference price; production; import; supply

\section{Introduction}

The price of agricultural products had always been a concern of government, especially the prices of products including basic goods. The government as a policy maker needed to pay attention to the price pattern that occurred, so as to be able to apply the right policy. The high price fluctuation made the pattern of price stabilization policy should be made by the government, due to changes in food prices can have an impact on the welfare of society $(\mathrm{Yu}, 2014)$. Prices were stable and affordable was important for the people especially those with low income (Nuryati and Farid, 2016).

In Indonesia, one of the agricultural commodities which become essential goods were red chilli. Red chilli as an ingredient seasoning of the most popular and widely cultivated in Indonesia (Jubaedah, 2013) because it was profitable when grown so it can increase farmers' income (Agung et al., 2000; Huq and Arshad, 2010; Baru et al., 2016; Mohd et al., 2016). World chilli production was currently dominated by China, but Indonesia was one of the world's largest chilli producing countries, and the Indonesian people are among the world's biggest chilli enthusiasts (Palar et al., 2016). 
Consumption of red chilli in Indonesia, had a highest consumption rate among other types of chilli, which amounted to $2.97 \mathrm{~kg} /$ capita/year in 2015. Demand was closely related to population growth (Ariningsih and Tentamia, 2004; Saifoel 2010; Parvathi and Arulselvam, 2013) as well as the demand for red chilli strongly related to the number of residents (Jubaedah, 2013). Red chilli demand in Indonesia tend to be stable, but can occur at any given moment boom, especially before and during religious holidays (Anwarudin et al., 2015). The high red chilli demand sometimes cannot be fulfilled by the availability of supplies, so it influenced in enhanced price of chilli (Estrades and Terra, 2012), the opposite happens when the harvest, the amount of the excess supply led to a decrease in the price of red chilli.

Goods that had high elasticity value, if there was an increase would be easily replaced with other items (Pons, 2011), but the majority of Indonesian people which were very enthusiast of red chilli in fresh form and not replaced with other products led to a demand of red chilli became inelastic to price (Farid and Subekti, 2012). Inelastic demand characteristics as well as agricultural products which cannot be stored longer (perishable) like chilli required the right policy if it wanted to put forward domestic products rather than imported product (Tschirley et al., 2015). Availability of red chilli was needed because of Indonesian society consumption is high, either used in fresh and processed form, thus requiring the management of deals to ensure price stability, if not then it may lead to increased prices and relies on imports (Zhou and Staatz, 2016).

Government intervention was needed depending on how important the commodity was in general in society. In addition to inflation contributing, price variations coefficients in consumer as an indicator to show whether the government should intervene to stabilize the price of a particular commodity (Ministry of Commerce, 2015). Red chilli, when compared with other essential commodities, have price coefficients of variation $31.68 \%$, higher than rice as the main staple food of Indonesian society and also higher than shallots as other important horticultural commodities with coefficients of variation $4.43 \%, 20.88 \%$,(Ministry of Commerce, 2015). In addition to having a high variation coefficient, red chilli was one commodity contributor to inflation or deflation, it was clear that red chilli prices were very volatile. Red chilli price increasing contributed the inflation around $0.4 \%$ in 2014, whereas in 2015 the deflation contributed by red chilli was $0.39 \%$, and in 2016 returned contribute to inflation of $0.35 \%$ (Bank Indonesia, 2017). Inflation on foodstuff was inflation predominantly influenced by shocks due to harvesting, natural disturbance, or factors of the domestic and international commodity prices development (Bank Indonesia, 2017), this condition would give an impact on price stability. The high value of the prices variations coefficients and contributing to inflation or deflation, was the reason for the government to determine the policy to make red chilli price be more stable.

Red chilli was the basic essentials which constantly and continuously consumption (Anwarudin et al., 2015), the availability and consumption of red chilli became important to consider in efforts to stabilize prices, because the red chilli was one commodity that had a large share, reflected from its inflation weight (Farid and Subekti, 2012). Inelastic demand caused the price control policy can be conducted through the supply side of red chilli. The supply of red chilli in Indonesia was still dominated by domestic production, but there was also an abundance of imports and exports. Red chilli characters were extremely sensitive to the seasons (Hamid and Haryanto, 2011), so It will have an impact on the instability of the supply amount of red chilli, and will affect the price of red chilli (Anwarudin et al., 2015). 
One of the government's policy in controlling the price was the import settings. Red chilli importation arrangements made by the government to maintain the supply. On the other study, to stabilize the market, many countries introduced policy-zone policy, together with the purchase of a product or price subsidies strategy (Li et al., 2013). In Indonesia, the price subsidy policy applied to the factor inputs such as fertilizer, but did not apply the price of food products.

The price of chilli in domestic market soared when compared with the price of chilli in the international market led to the domestic market is flooded with imported chilli commodities. It was also due to the absence of clear rules regarding the red chilli importation, which followed the regulations issued by the government of the horticultural products import systems from the quota system, to be the reference price system. The policy was done as importation management, beside to control the price of red chilli also done to encourage domestic red chilli production. Instead, Minot (2014) stated that commodities that had high price volatility, with government interference and trade barriers, often encourage seasonal volatility and exacerbate the surge in food prices due to supply shortages. Giordani et al. (2016) indicate that trade policy activity is increasing in order to protect the domestic economy in the wake of changes in international prices, even this policy is done to stabilize domestic prices. Hoang and Meyers (2015) in their research showed that trade liberalization caused the price increase to be worse, thus decreasing the income of farmers. The deference about this statement was interesting to be proven in this study.

Schreiner et al. (2013) see that the more fundamental issues of developing countries were to ensure the sustainability of food/product availability for every consumer as it will impact on the price of the commodity. The reference price policy was expected to drive red chilli deals, so this research aimed to see how the effectiveness of reference price policy in influencing red chilli supply through its influence on the import of red chilli in Indonesia and determined the factors that affected red chilli supply so it impacted to the prices stabilization.

This research had become interesting and important because it sought to see and prove how the impact of the government's red chilli price stabilization policy through import policy mainly through the application of price references in an econometric model. This research was also a material evaluation of how much influence of the policy on the price of red chilli and how the influence of other variables on the price of red chilli either directly or indirectly. The government's decision to stop both policies would have consequences for the stabilization of the price of red chilli, so that this study was expected to answer policy alternatives that can be done by the government to stabilize the price of red chilli.

\section{Materials and Method}

The data used in this study using secondary data in the period December 2010September 2016. Data obtained from the Central Bureau of Statistics, Ministry of Agriculture, Ministry of Trade, Trade Map, the Food and Agriculture Organization (FAO) and the relevant literature to the research topic.

This research attempted to capture an economic phenomenon on the behavior of red chilli price with suppression through the supply side, thus using an econometric model to answer research questions. A model representing an actual phenomenon that is an actual system or process (Ariningsih and Tentamia, 2004), and a model often used to analyze socioeconomic problems is the econometric model. Econometrics also means quantitative analysis of actual economic phenomena, based on theoretical develop- 
ments and observations, related to appropriate inference methods (Gujarati and Porter 2010).

The econometric model consists of single and simultaneous equations. A single equation is endogenous determined by one or more exogenous explanatory variables, so the causal relationship between an endogenous variable and exogenous variable is a one-way relationship. Simultaneous equations are an equation that forms a system of equations which form depends on the various variables in the equations. So the method of simultaneous equations is used to see the influence between the variables. In simultaneous equation models more than one dependent, or endogenous, variable is involved, necessitating as many equations as the number of endogenous variables. The endogenous variable (i.e., regressand) in one equation may appear as an explanatory variable (i.e., regressor) in another equation of the system (Gujarati, 2010).

The result of order condition of identifications can be seen from Table 1 and the model of the overidentified equation can be predicted using Two Stage Least Square (2SLS), Three Stage Least Square (3SLS), Limited Information Maximum Likelihood (LIML), Full Information Maximum Likelihood (FIML). The choices of the method is adjusted to the research need to obtain the coefficient of structural equation simultaneously. Overidentified equations can be used among others 2SLS as a single equation method and 3SLS as system method in simultaneous equation model,

Both of these methods have their advantages based on the result parameters. The advantages of the 2SLS method compared to 3SLS are simpler and easier to generate asymptotically consistent and efficient assumption parameters. The advantages of 3SLS are to generate more efficient, but highly sensitive, parameters for model specification changes and require more samples than 2SLS (Kutsoyiannis 1977). Based on these considerations, the simultaneous method chosen in estimating the model in this study is 2 SLS.

It is said to be overidentified if more than one numerical value can be obtained for some of the parameters of the structural equations (Gujarati, 2010). Yuliadi (2008) said an equation could be identified when the equation satisfies the following conditions:

1. If $K-\mathrm{k}>\mathrm{m}-1$, the equation is overidentified

2. If $\mathrm{K}-\mathrm{k}=\mathrm{m}-1$, the equation is exactly identified

3. If $\mathrm{K}-\mathrm{k}<\mathrm{m}-1$, the equation is underidentified

Where:

$\mathrm{M}=$ number of endogenous variables in the model

$\mathrm{M}=$ number of endogenous variables in a given equation

$\mathrm{K}=$ number of predetermined variables in the model including the intercept

$\mathrm{K}=$ number of predetermined variables in a given equation

Table 1. Results of Order Condition of Identifications

\begin{tabular}{lcccccc}
\hline Equation & $\mathrm{K}$ & $\mathrm{k}$ & $\mathrm{m}$ & $\mathrm{K}-\mathrm{k}$ & $\mathrm{m}-1$ & Identified \\
\hline Production of red & & & & & & \\
chilli & 19 & 6 & 1 & 13 & 0 & Overidentified \\
Red chilli import & 19 & 3 & 2 & 16 & 1 & Overidentified \\
Red chilli export & 19 & 3 & 3 & 16 & 2 & Overidentified \\
Price of red chilli & 19 & 3 & 2 & 16 & 1 & Overidentified \\
\hline
\end{tabular}


Red chilli supply models in Indonesia in this study consisted of five equation, four structural equation and the equation of identity. Structural equation consisted of the production of red chilli, red chilli import, red chilli export and red chilli prices, while the identity equation namely red chilli supply. HS code which was used to import and export the red chilli was is 0709601000 . Estimation parameters were taken at four structural equation.

\section{Indonesian Red Chilli Supply}

National red chilli supply was an identity that consists of the total production, the amount of exports minus imports (Ariningsih and Tentamia, 2004; Tajdini et al., 2012). The national red chilli supply equation can be formulated as follows:

$\mathrm{QSC}_{\mathrm{t}}=\mathrm{QCM}_{\mathrm{t}}+\left(\mathrm{IMC}_{\mathrm{t}}-\mathrm{XC} \mathrm{C}_{\mathrm{t}}\right)-\mathrm{QT}_{\mathrm{t}}$

\section{Indonesian Red Chilli Production}

National red chilli production during year $\mathrm{t}$ was a function by using approach of commodity price, input price alternative, and value alternative from other variables affecting supply. The use of basis price fertilizers was NPK fertilizer based on research conducted by Farid and Subekti (2012) and Sukmawati (2014). The red chilli production equation can be written as follows

$\mathrm{QCM}_{\mathrm{t}}=\mathrm{a}_{0}+\mathrm{a}_{1} \mathrm{LHN}_{\mathrm{t}}+\mathrm{a}_{2} \mathrm{UTK}_{\mathrm{t}}+\mathrm{a}_{3} \mathrm{HPR}_{\mathrm{t}}+\mathrm{a}_{4} \mathrm{PNr}_{\mathrm{t}}+\mathrm{a}_{5} \mathrm{CH}_{\mathrm{t}}+\mathrm{a}_{6} \mathrm{DR}_{\mathrm{t}}+\mathrm{u}_{1 \mathrm{t}}$

Sign of the expected parameters: $\mathrm{a}_{1}, \mathrm{a}_{3}, \mathrm{a}_{5}, \mathrm{a}_{6}>0 ; \mathrm{a}_{2}, \mathrm{a}_{4}<0$

\section{Indonesian Red Chilli Import}

Red chilli import equation can be written as follows:

$\mathrm{IMC}_{\mathrm{t}}=\mathrm{b}_{0}+\mathrm{b}_{1} \mathrm{IMC}_{\mathrm{t}-1}+\mathrm{b}_{2} \mathrm{RPIC}_{\mathrm{t}}+\mathrm{b}_{3} \mathrm{QCM}_{\mathrm{t}}+\mathrm{b}_{4} \mathrm{DR}_{\mathrm{t}}+\mathrm{u}_{2 \mathrm{t}}$

Sign of the expected parameters: $b_{1}>0 ; b_{2}, b_{3}, b_{4}<0$

\section{Indonesian Red Chilli Export}

Red chilli export equation can be expressed as follows:

$\mathrm{XC}_{\mathrm{t}}=\mathrm{c}_{0}+\mathrm{c}_{1} \mathrm{XC}_{\mathrm{t}-1}+\mathrm{c}_{2} \mathrm{RPXC}_{\mathrm{t}}+\mathrm{c}_{3} \mathrm{QCM}_{\mathrm{t}}+\mathrm{c}_{4} \mathrm{NTX}_{\mathrm{t}}+\mathrm{c}_{5} \mathrm{IMC}_{\mathrm{t}}+\mathrm{u}_{3 \mathrm{t}}$

Expected parameter signature: $\mathrm{c}_{1}, \mathrm{c}_{2}, \mathrm{c}_{3}>0 ; \mathrm{c}_{4}, \mathrm{C}_{5}<0$

\section{Price of Indonesian Red Chilli}

Red chilli prices allegedly affected by Indonesia red chilli supply, the price of red chilli in the previous period, import prices and producer levels price. The price equation of red chilli can be written as follows:

$\mathrm{HCM}_{\mathrm{t}}=\mathrm{e}_{0}+\mathrm{e}_{1} \mathrm{HCM}_{\mathrm{t}-1}+\mathrm{e}_{2} \mathrm{QSC}_{\mathrm{t}}+\mathrm{e}_{3} \mathrm{PICR}_{\mathrm{t}}+\mathrm{e}_{4} \mathrm{HPR}_{\mathrm{t}}+\mathrm{u}_{4 \mathrm{t}}$

Sign of the expected parameters: $\mathrm{e}_{1}, \mathrm{e}_{3}, \mathrm{e}_{4}>0 ; \mathrm{e}_{2}<0$

Where:

$\mathrm{QSC}_{\mathrm{t}} \quad=$ Indonesia red chilli supply on $\mathrm{t}$ period (ton)

$\mathrm{QCM}_{\mathrm{t}} \quad=$ Indonesian red chilli production on $\mathrm{t}$ period (ton)

$\mathrm{IMC}_{\mathrm{t}} \quad=$ Indonesia fresh chilli import volume on $\mathrm{t}$ period (ton)

$\mathrm{XC}_{\mathrm{t}} \quad=$ Indonesia fresh chilli export volume on $\mathrm{t}$ period (ton)

$\mathrm{HCM}_{\mathrm{t}}=$ Large red chilli retail real price on $\mathrm{t}$ period $(\mathrm{Rp} / \mathrm{Kg})$

$\mathrm{LHN}_{\mathrm{t}} \quad=$ Red chilli harvest area on $\mathrm{t}$ period $(\mathrm{Ha})$

UTK $_{\mathrm{t}} \quad=$ Real wage employment on $\mathrm{t}$ period $(\mathrm{Rp} / \mathrm{HOK})$

$\mathrm{HPR}_{\mathrm{t}} \quad=$ Real price of red chilli producer level $(\mathrm{Rp} / \mathrm{Kg})$

$\mathrm{PNR}_{\mathrm{t}} \quad=$ Real price of subsidized basic fertilizer $(\mathrm{Rp} / \mathrm{Kg})$

$\mathrm{CH}_{\mathrm{t}} \quad=$ dummy optimal rain bulk on $\mathrm{t}$ period 


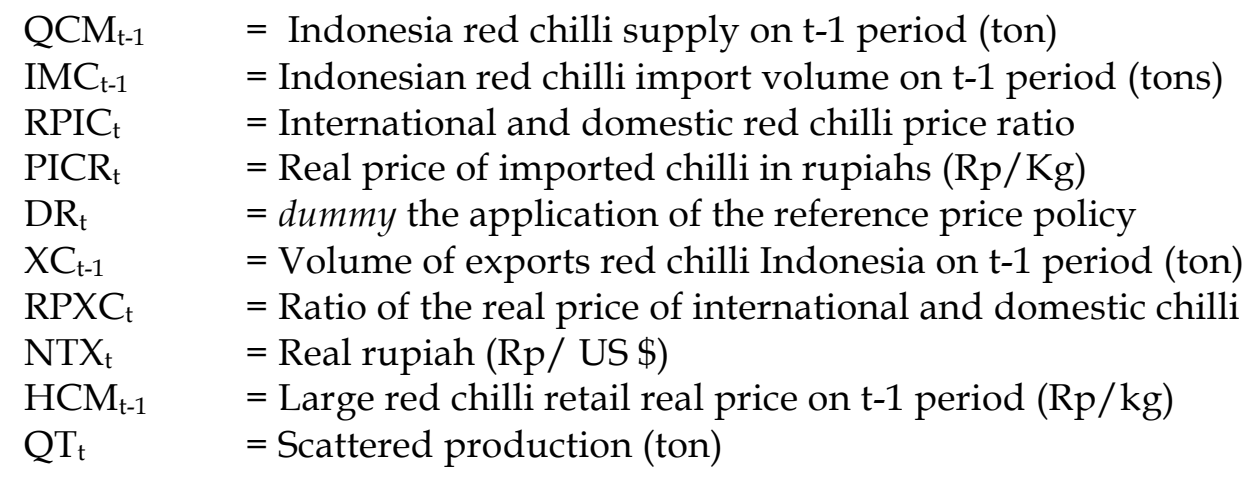

\section{Results and Discussion}

This study wanted to see the effect of applying the red chilli reference price policy of red chilli prices through bid management. In general, the Indonesian red chilli supply model showed good results. The test results in Table 1 did not indicate a multicollinearity problem, because the calculation results showed the value of each predictor variable in each equation indicate the variance inflation factor (VIF) of less than 10 as the limit of tolerance which there was not a problem multicollinearity $(\mathrm{O}$ 'B rien, 2007; Natale, et al., 2015; Widarjono, 2016). Serial correlation test (autocorrelation) performed using Breusch-Godfrey Serial Correlation LM test and heteroscedasticity test using White test. Autocorrelation test results in Table 2 showed only one equation that has the problem, namely the price of red chilli.

Table 2. Results of Autocorrelation, Multicollinearity, and Heteroscedasticity in Structural Equation

\begin{tabular}{|c|c|c|c|c|c|}
\hline \multirow{2}{*}{ Equation } & \multicolumn{2}{|c|}{ Autocorrelation } & \multirow[t]{2}{*}{ Multicollinearity } & \multicolumn{2}{|c|}{ Heteroscedasticity } \\
\hline & Probability & Conclusion & & Probability & Conclusion \\
\hline & & $\mathrm{No}$ & No problem & & $\mathrm{No}$ \\
\hline $\mathrm{QCM}_{\mathrm{t}}$ & 0.2277 & problem & & 0.1712 & problem \\
\hline & & No & No problem & & \\
\hline $\mathrm{IMC}_{\mathrm{t}}$ & 0.058 & problem & & 0.0000 & problem \\
\hline & & No & No problem & & \\
\hline $\mathrm{XC}_{\mathrm{t}}$ & 0.0622 & problem & & 0.0000 & problem \\
\hline $\mathrm{HCM}_{\mathrm{t}}$ & 0.0058 & problem & No problem & 0.0092 & problem \\
\hline
\end{tabular}

Heteroscedasticity test in Table 2 showed only red chilli production that did not have problems. Heteroskedastisitas problem corrected using white method by developing a standard error corrected to produce an estimator super and consistent so it will be valid for statistical tests, while the same problems with autocorrelation heteroscedasticity corrected using Heteroskedasticity method and Autocorrelation Consistent Covariance (HAC) (Widarjono, 2016).

\subsection{Production of Red Chilli}

The results of equation estimating Indonesian red chilli in Table 3 showed that the production of red chilli was significantly influenced by five estimated variables and one variable estimator did not affect the production of red chilli. The variables that significantly influence was the harvest area, the real price of manufacturers level, the real price of subsidized fertilizer, dummy rain bulk and dummy reference price. The increase in harvest area positively affected the production of red chilli with coefficient 
amounted to 3.38 , but the production of red chilli was not responsive enough to changes in harvested area or inelastic with elasticity value of 0.952 . This inelastic nature was also seen from the average value of red chilli productivity in Indonesia of 8.65 tons/ha which means it was still below the potential productivity of prime red chilli like Tanjung 1, Tanjung 2, Lembang 1, Ciko, Lingga and Kencana which can reach 10 tons/ha, even the potential for superior seed was able to reach 15-21 tons/ha (Setiawati et al., 2015).

Table 3. Results of The Equation Estimation Indonesia Red Chilli Production

\begin{tabular}{lrrlrr}
\hline Variable & Coefficient & t-Statistic & Prob. & \multicolumn{2}{c}{ Elasticity } \\
\cline { 4 - 6 } & & & & Short Run & Long Run \\
\hline $\mathrm{C}$ & 118745.30000 & 1.01913 & 0.3121 & & \\
LHN $_{\mathrm{t}}$ & 3.37962 & 12.61643 & $0.0000^{*}$ & 0.9517 & 1.1863 \\
$\mathrm{UTK}_{\mathrm{t}}$ & -1.47240 & -0.66431 & 0.5090 & -0.6736 & -0.8397 \\
$\mathrm{HPR}_{\mathrm{t}}$ & 2.34687 & 3.84662 & $0.0003^{*}$ & 0.4335 & 0.5404 \\
PNR $_{\mathrm{t}}$ & -53.99870 & -3.59299 & $0.0006^{*}$ & -1.3257 & -1.6525 \\
$\mathrm{CH}_{\mathrm{t}}$ & 2557.08400 & 1.75048 & $0.0850^{* *}$ & 0.0153 & 0.0191 \\
$\mathrm{QCM}_{\mathrm{t}-1}$ & 0.19775 & 2.85718 & $0.0058^{*}$ & 0.0003 & 0.0003 \\
\hline $\mathrm{R}$ & 0.88 & & & & \\
$\mathrm{~F}$ & 74.57 & & & & \\
\hline
\end{tabular}

Note: $\left({ }^{*}\right),\left({ }^{* *}\right)$ denote significant level of $5 \%$ and $10 \%$ respectively

The opposite response was shown by the production of red chilli on changes in subsidized fertilizer with a value of -1.326 elasticity which mean an increase in the price of fertilizer caused a decrease in red chilli production and when the decline in fertilizer prices leads to an increase in the production of red chilli. This elasticity value illustrated the importance of fertilizer for red chilli farmers. The nature of the price of fertilizer which had elasticity was also due to the cost of fertilizer was one component of big red chilli production costs except for pesticides (Farid and Subekti, 2012).

Based on the analysis, the price of red chilli in producer level showed a positive influence, however number of red chilli production was not responsive enough toward producer prices changes. It was due to farmers as producers cannot immediately increase production when prices have increased (Farid and Subekti, 2012). In fact, chilli price movements in producer was a lot of influence of the city or collector who has a major role in determining the price, so the ups and downs of the production of red chilli did not significantly affect the price (Sukmawati, 2014).

The use of input production was influenced by the input price. If the prices of fertilizers were significant effect, as opposed to wages of agricultural laborers changes who did not significantly affect the number of red chilli production. This was because generally the red chilli farmers did not use the land was so vast, so it was not much needed labor. Farmers prefer to work alone or used workers coming from its own farm households.

Climate change or irregular season variation would affect the agricultural ecosystem and human life, especially people in developing countries with the lack condition of socio-economic and highly dependent on the agricultural sector (Darma, et al., 2014), so climate change was the important factor for production. The impact of climate change was movement time of the rainy and the dry season that the important factor of red chilli cultivation. Rainfall was technically affected the red chilli production, however, the production of red chilli continuity was maintained. This was due to the development of quality seed technological and reasonably resistant to the changing 
seasons. Characteristics of the better red chilli planted in conditions not too wet and not too dry, and had a production peak period at the end of the rainy season. Best chilli was produced during the rainy season than during the dry season (Fitriana, 2015), however, rainfall was too high can also cause a variety of diseases and pests so that made the higher risk of failure (Anwarudin, et al., 2015). Rainfall between 100-250 $\mathrm{mm} /$ month was considered sufficient to produce chilli with moderate to high productivity (Sebayang, 2014), so that the optimal rainfall conditions can increase the production of good results. The estimation results indicate optimum rainfall dummy positive effected and with coefficient 2557.084 . This means that when rainfall was in the range of $100-250 \mathrm{~mm} /$ month, the production of red chilli will increase by 2557.084 ton and when rainfall was less than $100 \mathrm{~mm} /$ month or more than $250 \mathrm{~mm} /$ month then the production will decrease by 2557.084 Ton.

\subsection{Import of Red Chilli}

The main objective of the application of the reference price policy was as a form of control over imports, which in this study was red chilli commodity. As one of the country's largest producer and chilli fan, made the government feel the need to protect against the product. The difference of international and domestic price made an opportunities to do the import for the international trader. As a member of the WTO and AFTA, Indonesia had a mandate to open farm enter into trade liberalization. Trade liberalization to open market access with the reduction of trade barriers (Marliyana and Wahjoe, 2015). One form of government protection against production and domestic industry by doing imports manage through reference prices. A form of protection by the government was a reference price as a form of Non-Tariff Measures (NTM) were classified in this kind of Price Control Measures, Including Additional Taxes and Charges (Reza, 2015). This reference price policies regulated the importation of some commodities that included such as red chilli using the reference price approach. In addition to the domestic producers protection, reference prices were also made as prices management as an effort to prices stabilize if the red chilli price soared.

The market price that was higher than the reference price may be considered for import while the market price was lower than the reference price, it was necessary to import. This was done to reduce the addicted import so that farmers were able to compete with foreign products and domestic needs were expected to be met from domestic production.

Based on the estimation of the model, the variables that had a significant influence on import was the international prices ratio with domestic prices that had a negative influence as presented in Table 4 . This means that if the international red chilli prices increased or decreased in domestic chilli prices, it can reduce the amount of imports. Price showed as a factor that has a strong influence on the amount of imports, seen in response to the amount of red chilli imports toward changes in elastic price ratio value both short and long term, with the value of -1.027 and -2.95 . This result was accordance with the research conducted by Fuller et al. (1992) which concludes that the import of a commodity was also affected by the import price and the domestic price of the commodity. 
Table 4. Results of The Estimation Equation Indonesian Red Chilli Import

\begin{tabular}{cccccc}
\hline Variable & Coefficient & \multirow{2}{*}{ t-Statistic } & Prob. & \multicolumn{2}{c}{ Elasticity } \\
\cline { 5 - 6 } & & & & Short Run & Long Run \\
\hline $\mathrm{C}$ & 188.24600 & 1.49885 & 0.1388 & & \\
$\mathrm{IMC}_{\mathrm{t}-1}$ & 0.65200 & 2.97773 & $0.0041^{*}$ & 0.6640 & 1.9074 \\
$\mathrm{RPIC}_{\mathrm{t}}$ & -194.36700 & -2.47084 & $0.0162^{*}$ & -1.0273 & -2.9511 \\
$\mathrm{QCM}_{\mathrm{t}}$ & -0.00018 & -0.12973 & 0.8972 & -0.1340 & -0.3848 \\
$\mathrm{DR}_{\mathrm{t}}$ & -30.61640 & -0.80662 & 0.4229 & -0.1388 & -0.3987 \\
\hline $\mathrm{R}^{2}$ & 0.56 & & & & \\
$\mathrm{~F}$ & 20.26 & & & & \\
\hline
\end{tabular}

Note: $\left(^{*}\right)$ denote significant level of $5 \%$

The import management policy had undergone several changes. The management of imports in the period of 1998-2004 applied the tariff policy with the imposition of import tariff of $5 \%$. Since January 2005, there had been a policy change, Indonesia enforces the Harmonization of Import Duty Tariff by determining tariff increase for some agricultural products, including horticultural horticulture products, one of which was also increasing the import duty tariff from $5 \%$ to $10 \%$. This was done as a form of control of red chilli imports, in addition to reducing dependence on imported products, as well as a protection against domestic products.

Along with the development of international trade in the era of Free Trade Areas of the ease of trading systems developed by the imposition of a zero percent rate. Government protection against red chilli with import product entrance restrictions, at the same time with this rule then also set the landing place of imports fruit and vegetable which took effect in June 2012, and also set a rule of plant quarantine measures which enter Indonesia either vegetables as well as fresh fruit, included red chilli in it. The entrance of imported horticulture products was limited to four entrances, namely Soekarno Hatta Airport, Port of Tanjung Perak, Belawan and Makassar. Tanjung Priok port which can be accessed by the countries who obtain MRA (mutual recognition agreement) from the Indonesian government, namely Canada, the US, Australia and New Zealand, but later developing countries acquire MRA namely the Netherlands, France and Pakistan. Indonesia's policy then got a lawsuit by the United States (US) to the World Trade Organization (WTO), because it was considered detrimental in United States export to Indonesia, because there were some products from the US who cannot get into Indonesia the main reason that the horticultural products in the country were still insufficient to meet domestic needs, including within it was red chilli commodity.

The next policy was the stipulation of import regulations on horticultural products by eliminating the rules concerning restrictions on the entrance and use the reference prices for import of horticultural products. This reference price was the price set by the government by calculating the production costs and profits of farmers and retailers, and became a reference in the importation of some products regulated therein.

Reference prices undergo several developments tailored to the analysis of government teams deciding on the value of reference prices. The reference price of the last set in 2016, with the amount of the reference price of red chilli Rp 15 000, - for purchase at the farm level and Rp 28 500, - for sales at the consumer level. When the retail price is 15 percent above the reference price it can be considered to import, this is done to control the price increases and returns stable.

The application of the reference price of this study analysis result showed that the reference price policy had no significant effect in reducing the number of red chilli 
imported. The number of imports of red chilli can be suppressed so that the fulfillment of domestic needs is expected to come from within the country. However there was no guarantee that the enforcement of this policy did not cause prices to be more stable, because red chilli import arrangements should be done at the right time to do the import of red chilli, when the supply was less than demand. Total production in this study also showed no significant effect and inelastic against imports, due to high production did not guarantee that there was the need for imports. Imports should be done if the domestic need not be met by domestic production. If imports decreased in these conditions, then there was an increase in the price of red chilli as shown in Figure 1 , as illustrated in 2016.

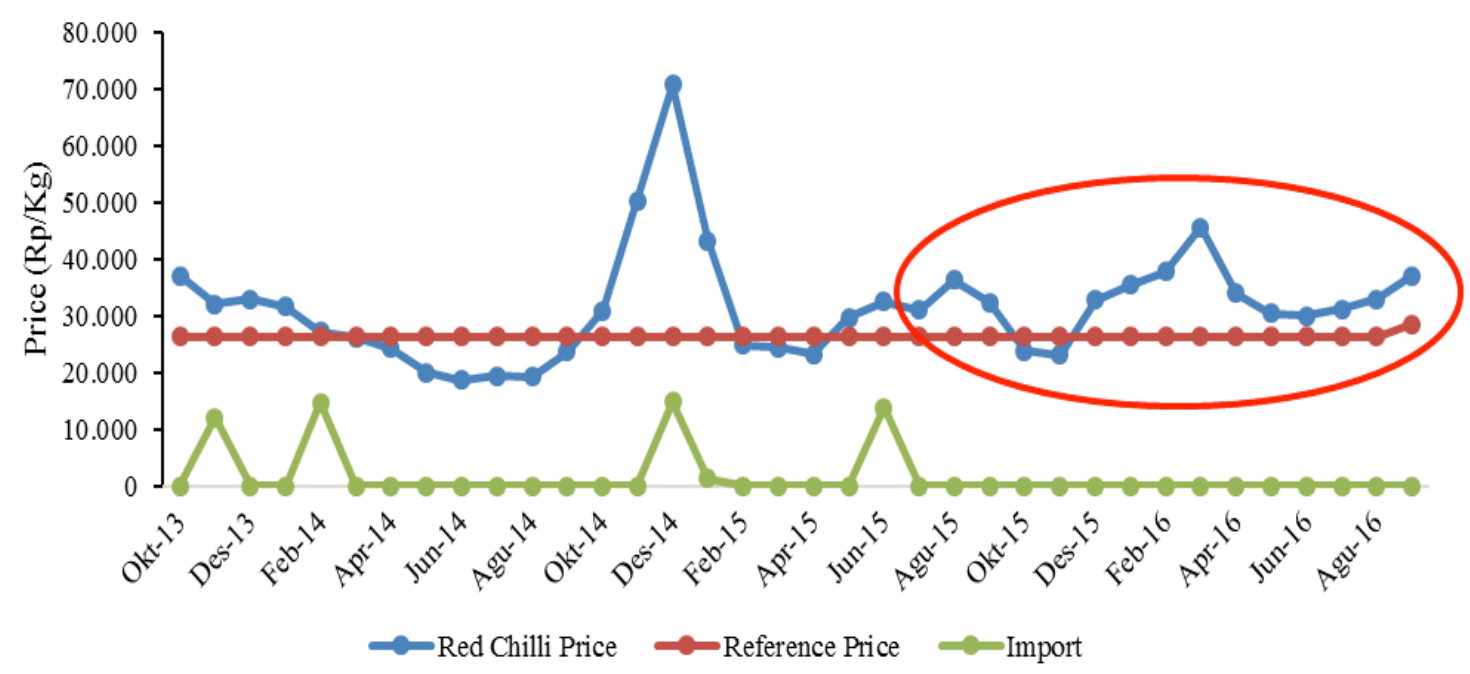

Figure 1. Chilli Red Price Comparison, Reference Price and Red Chilli Import Volume Chart Source: BPS and Ministry of Trade (2016)

Prices often rose sharply and were above the reference price, it should be a signal that there is a shortage of supply, thus causing price increases. Based on these considerations, imports should be within reasonable limits, but the government did not open imports, causing prices to fluctuate prolonged most of the year. It also proved that the implementation of the reference price policy was not strong enough to do, government intervention in opening or closing the imported faucet cannot ensure price stabilization. If production was not strengthened to support the domestic demand that was difficult to predict, especially the industrial sector that increasingly used red chilli as raw material.

The application of the reference price intended for managing imported red chilli so prices were more stable and ultimately expected to encourage domestic production of red chilli to met domestic needs and even to increase exports, so the increase in production was expected to further reduce the number of imported red chilli.

\subsection{Export of Red Chilli}

Indonesia red chilli export was not in the top ten areas in the world's largest exporter, though Indonesia was the fourth largest producer in the world. This was due to high domestic consumption, so that production was preferred to meet the needs of the domestics commodity. The study also wants to see how the impact of applying the reference price policy to red chilli exports in Indonesia. The analysis showed that the 
application of the reference price that can reduce the amount of imports, may indirectly increase the amount of exports. This was evident from the effects of red chilli import to red chilli export had a negative effect. However, both short-term and longterm, red chilli exports were unresponsive to changes in red chilli imports or inelastic. The cause of the inelastic response of red chilli exports to the amount of red chilli imports, was due to the too small value when compared with domestic red chilli production, so the decrease in the amount of imports was not much effect on the amount of red chilli exports as shown in Table 5.

Table 5. Results of The Estimation Equation Indonesian Red Chilli Export

\begin{tabular}{cccccc}
\hline Variable & Coefficient & \multirow{2}{*}{ t-Statistic } & Prob. & \multicolumn{2}{c}{ Elasticity } \\
\cline { 5 - 6 } & & & & Short Run & Long Run \\
\hline $\mathrm{C}$ & 24.73372 & 0.828198 & 0.4107 & & \\
$\mathrm{XC}_{\mathrm{t}-1}$ & 0.58553 & 2.030118 & $0.0466^{*}$ & 0.5774 & 1.6588 \\
$\mathrm{RPC}_{\mathrm{t}}$ & 2.82128 & 0.218869 & 0.8275 & 0.0594 & 0.1706 \\
$\mathrm{QCM}_{\mathrm{t}}$ & 0.00018 & 0.664187 & 0.509 & 0.5455 & 1.5670 \\
$\mathrm{NTX}_{\mathrm{t}}$ & -0.00212 & -1.22002 & 0.227 & -0.9823 & -2.8217 \\
$\mathrm{IMC}_{\mathrm{t}}$ & -0.02048 & -1.38844 & $0.1699^{* * *}$ & -0.0843 & -0.2422 \\
\hline $\mathrm{R}^{2}$ & 0.40 & & & & \\
$\mathrm{~F}$ & 8.61 & & & & \\
\hline
\end{tabular}

Note: $\left({ }^{*}\right),\left({ }^{* * *}\right)$ denote significant level of $5 \%$ and $20 \%$ respectively

Estimates variable of other red chilli exports, in this study showed results that did not differ significantly. The international and domestic price ratios, domestic red chilli production, and exchange rate indicate that these three variables had no significant effect.

This result contrary to Kumar and Dawan (1991) which showed that export was affected by exchange rates against foreign currencies, the ratio of export and domestic prices. Havrial and Gunawardana (2006) also showed that an increase in domestic production had an effect on export growth. The difference results in this study with previous research indicate that Indonesian red chilli export had difficulty to see the influence of explanatory variables in the model.

The less of export value and relatively not much increase caused difficulty to see the influence of explanatory variables in the model. The high demand for red chilli in Indonesia caused the increase in production to be absorbed by domestic demand so that the need for export only on certain types of chilies and in small quantities, so it did not depend on the international price or currency exchange rate.

Similar to the results of the analysis of import equations, the high consumption of red chilli caused the difficulty of predicting the number or behavior of red chilli exports. The high level of demand both for consumption in the form of fresh and raw materials for other processed products, caused red chilli exports only become side targets, had not become the main target yet.

If you look at export opportunities, it was actually pretty wide open, proven by amount of red chilli Indonesian importing countries increasingly diverse, as shown in Table 6 . This opportunity should be utilized by the government, by strengthening the production of red chilli continuity, not only to meet domestic needs but also address the export cash mop wide open. Red chilli is mainly export to Malaysia, Singapore, Saudi Arabia, Qatar, Japan for 5 years recently. Although, the export volume decreased in Qatar, but another country has grown up dramatically especially Singapore. It might 
due to the rise in production of chilli during last few year that has boosted Indonesia"s chillies export opportunities (Jubaedah, 2013).

Table 6. Development of Indonesian Fresh Red Chilli Export Volume by Country 2011-2015

\begin{tabular}{ccccccc}
\hline \multirow{2}{*}{ No } & \multirow{2}{*}{ Country } & \multicolumn{5}{c}{ Weight $(\mathrm{Kg})$} \\
\cline { 3 - 7 } & & 2011 & 2012 & 2013 & 2014 & 2015 \\
\hline 1 & Malaysia & 634050 & 72489 & 280397 & 17543 & 178855 \\
2 & Singapore & 93715 & 18009 & 34845 & 10491 & 208028 \\
3 & Saudi Arabia & 2259 & 25436 & 23015 & 15882 & 67778 \\
4 & Qatar & 0 & 1344 & 3924 & 2319 & 3867 \\
5 & Japan & 0 & 460 & 8277 & 8459 & 2856 \\
6 & Others & 2767 & 161 & 285 & 3916 & 6020 \\
\hline
\end{tabular}

Source: Trade Map (2016)

\subsection{Red Chilli Prices}

Fluctuations in the price of red chillis that occurred in Indonesia seemed to be a problem that arose repeatedly. Continuity of production was absolutely necessary to maintain price stability, because the demand for red chilli was difficult to control as it related to the behavior of people, markets, industries and took more time than the control factor red chilli deals. The role of government was needed in stabilizing the essential goods price, one of which was red chilli. In this study the model was built through several equations which one of them was the price equation of red chilli.

Two factors had great influence on the formation of the price of chilli by Deaton and Laroque (1992); Chambers and Bailey (1996), namely 1) the factors of production/harvest (harvest disturbance), and 2) the behavior of storage (storage/inventory behavior). Price fluctuations can also be caused by various factors such as high demand, low availability, macroeconomic conditions (depreciation of the currency against major world currencies and speculation in agricultural markets), weather and government policy interference (Estrades and Terra, 2012). Indrawati (2013) also showed that the price was influenced by the supply of commodities that mean big influence of red chilli deals price. This means that production factor, supply availability became one of the main factors affecting the price.

The results of the analysis of price in Table 7 showed that the prices of red chilli were influenced significantly by the red chilli deals, in addition to the price of red chilli was also influenced by the real price of red chilli previous period, the producer level real price and the dummy reference price.

Table 7. Results of The Equation Estimation Indonesian Red Chilli Price

\begin{tabular}{cccccc}
\hline Variable & Coefficient & \multirow{2}{*}{ t-Statistic } & Prob. & \multicolumn{2}{c}{ Elasticity } \\
\cline { 5 - 6 } & & & & Short Run & Long Run \\
\hline $\mathrm{C}$ & -13528.8 & -1.7938 & 0.0777 & & \\
HCM $_{\mathrm{t}-1}$ & 0.5170 & 4.8487 & $0.0000^{*}$ & 0.5182 & 1.4885 \\
$\mathrm{QSC}_{\mathrm{t}}$ & -0.0870 & -1.3138 & $0.1937^{* * *}$ & -0.3070 & -0.8820 \\
PICR $_{\mathrm{t}}$ & 0.0898 & 0.7326 & 0.4665 & 0.0515 & 0.1479 \\
HPR $_{\mathrm{t}}$ & 1.8489 & 4.5697 & $0.0000^{*}$ & 1.2751 & 3.6630 \\
DR $_{\mathrm{t}}$ & 2547.525 & 1.6723 & $0.0994^{* *}$ & 0.0586 & 0.1683 \\
\hline R-Sq & 0.5339 & & & & \\
F-hit & 18.31 & & & & \\
\hline
\end{tabular}

Note: $\left({ }^{*}\right),\left({ }^{* *}\right),\left({ }^{* * *}\right)$ denote significant level of $5 \%, 10 \%$ and $20 \%$ respectively 
Reference pricing policy was expected to boost domestic production by restricting the import of red chilli, so as to encourage farmers to increase production. Increased production can increase the availability or red chilli deals so that prices became more stable. The results of the analysis showed that the supply of red chilli negative effect on the price of red chilli . But the price of red chilli response to changes in supply less responsive or inelastic-term short- term and long with elasticity values respectively 0.31 and -0.88 . This illustrates that the continuity of production had not been able to be done optimally, so we need other measures to improve the elasticity value, in order to stabilize the price of red chilli easier.

The different things shown in red chilli price variables that change in producer responded more elastic by the price of retail red chilli. Red chilli prices manufacturers directly affected the price of real retail chilli red, as it became the purchase price before sold to consumers. Prices of real retail red chilli responsive to changes in the level of producer prices of red chilli, both short and long term with a value of 1.288 and 3.66. So, the ups and downs of the retail price of red chilli strongly influenced by the rise and fall of prices at the producer level. Producer level price was the price received by farmers. Red chilli price received by farmers was also determined by the extent of the amount produced, so it was important to consider the amount of red chilli production.

The highly elastic retail price response due to price changes at the producer level was indicated by the high price variation between producer and consumer level. The price of red chilli at the producer level greatly affected the price of red chilli at the retail level, this is in accordance with the Ministry of Commerce data (2016), that the disparity of the price of red chilli at producer and consumer level was very high as shown in Table 8.

Tabel 8. Average Disparity and Disparity Variation Coefficient Value of Red Chilli Price at Producer and Consumer Level

\begin{tabular}{ccc}
\hline Year & $\begin{array}{c}\text { Average Disparity of Red } \\
\text { Chilli Price at Producer and } \\
\text { Consumer Level (\%) }\end{array}$ & $\begin{array}{c}\text { Disparity Variation Coefficient Value } \\
\text { of Red Chilli Price at Producer and } \\
\text { Consumer Level (\%) }\end{array}$ \\
\hline 2010 & 42.70 & 86.94 \\
2011 & 35.82 & 108.74 \\
2012 & 21.15 & 71.05 \\
2013 & 55.41 & 35.03 \\
2014 & 55.98 & 122.51 \\
2015 & 42.33 & 60.27 \\
2016 & 59.39 & 27.43 \\
\hline
\end{tabular}

Source: Ministry of Commerce (2016) (processed)

The high disparity of red chilli price between producer and consumer level required the presence of a capable institution to control the condition, both government and parties in the red chilli supply chain. The very high fluctuations at the consumer level and not as high at producer level as shown in Figure 2 illustrated that there were other factors in the supply chain affected the increase of red chilli price. 


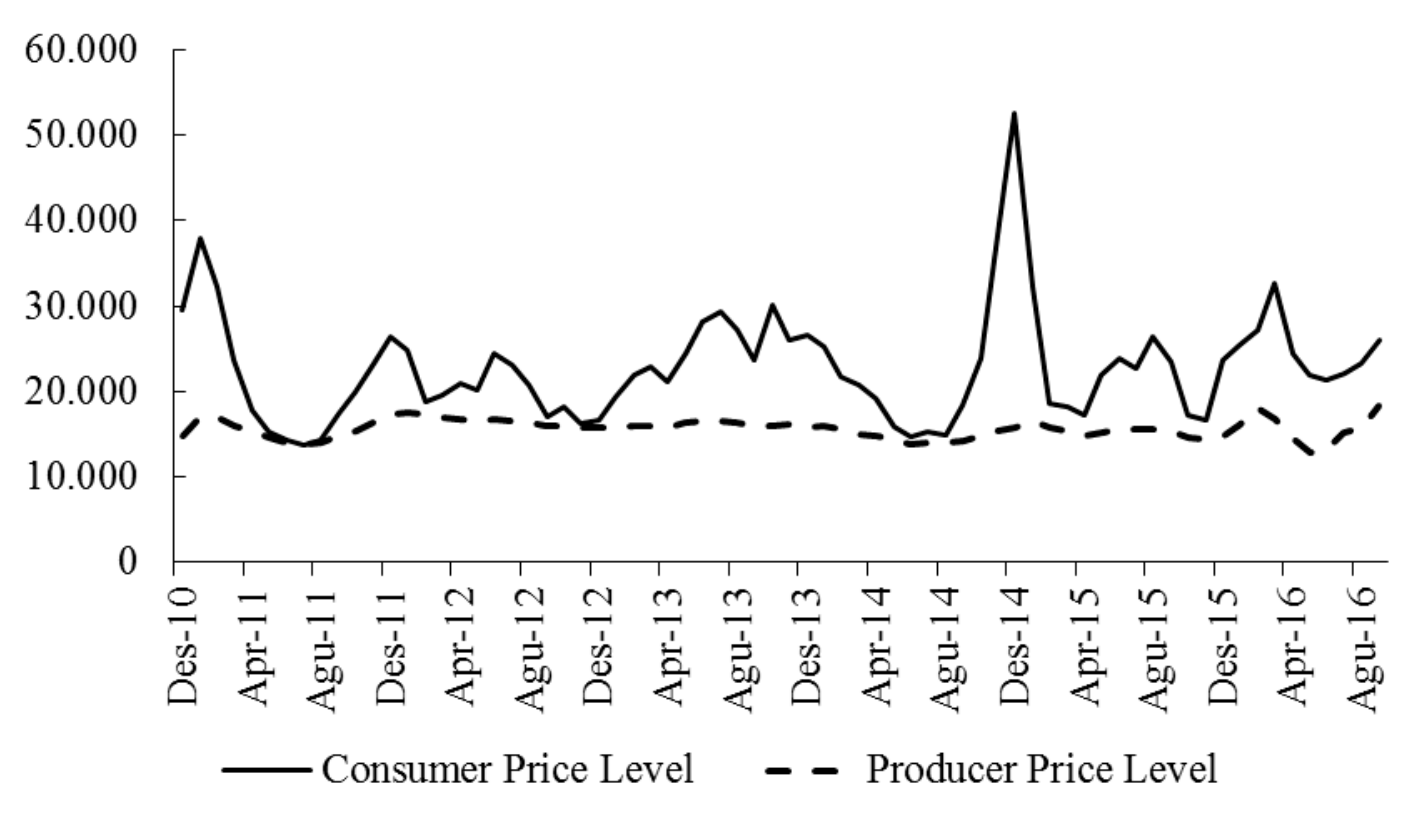

Figure 2. Red chilli prices at producer and consumer level 2011-2016

Source: Ministry of Commerce and Ministry of Agriculture (2016)

This research does not explain the detail problems in red chilli supply chain, but based on the information and evidence obtained, one of the causes of a high disparity between producer and consumer price was the presence of a mismatch in price formation at the consumer level. The fluctuated red chilli prices problem at the retail level and sometimes seem unnatural was also suspected caused by the cooperation of business actors to gain high profits that caused the market was not running properly. Such cooperation could lead to unhealthy business competition that distorted markets and led to market failures.

Red chilli consumption in Indonesia was relatively stable seen from the growth of red chilli consumption. Red chilli is the most consumed chilli type by the people of Indonesia, followed by cayenne chilli and green chilli. Red chilli mostly consumed by households with a share of use reached 51.6 percent of the domestic chilli total consumption, the rest was used as industrial raw materials, hotels, restaurants, catering, stalls, and used for export potential as shown in Figure 3.

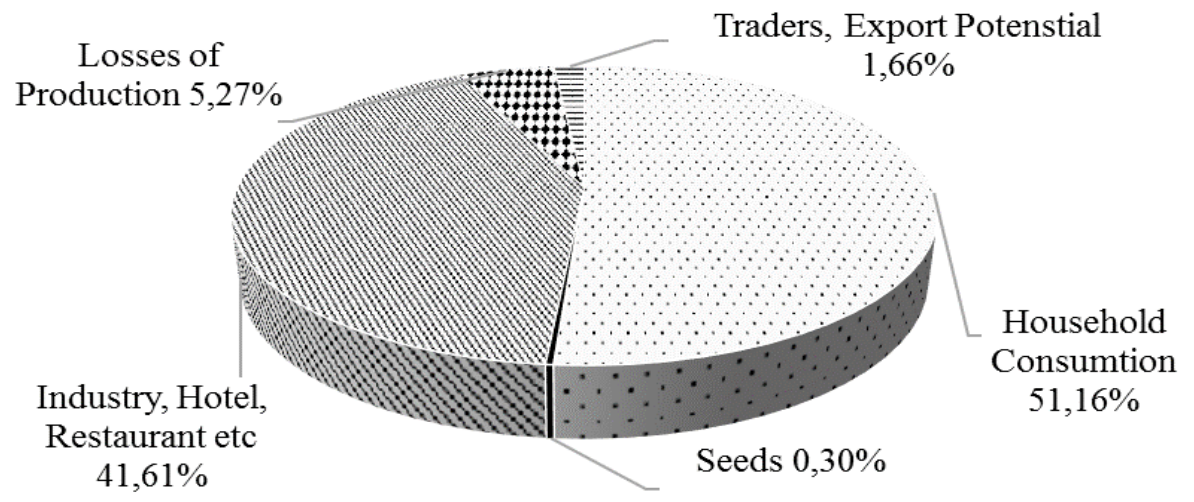

Figure 3. Composition of Red chilli Consumption in 2016

Source: Center for Information Data of Ministry of Agriculture (2016) (processed) 
Based on Susenas data, the red chilli consumption tends to increase every year with an average increase of 1.5 percent per year. If the estimated population of Indonesia in 2016 amounted to 258705 million people, then the needs of household red chilli consumption reached 593469 tons with the consumption rate of $2.29 \mathrm{~kg}$ per capita per year. This amount of consumption was slightly lower when compared to household needs in 2015 reached 759232 tons with consumption rate of $2.97 \mathrm{~kg}$ per capita per year.

The high chilli demand for direct consumption and industry caused irresponsible perpetrators to gain higher profits, by working with other business actors to set high prices for the industry. The high level chilli demand for industry caused the industry with strong capital capable to pay chilli at a higher price than the market. So, the chili that should be circulating in the market will be absorbed into the industry. This is what causes the scarcity in the market, thus causing the price to rise unnaturally. Cooperation amongst business actors may inhibit the distribution of chili on the market and cause unfair business competition.

Fresh red chilli in Indonesia had a very inelastic demand which amounted 3.16 percent when a price increase of 110 percent, or demand elasticity of 0.029 percent (Ali 2006). This shows the elasticity of the demand was very inelastic, so that affected the red chilli prices when there was a change in the variables of the red chilli prices. The elasticity of demand and supply of red chilli was very inelastic, this had a major impact on the red chilli prices. The decline in the number of production caused a decrease in the number of red chilli demand, resulted in scarcity in the market. The decrease of red chilli demand caused the supply curve to shift to the top left, and caused the equilibrium point to change from $E_{1}$ to $E_{2}$, as shown in Figure 4 . The equilibrium price changed from $P_{1}$ to $P_{2}$. The inelastic red chilli demand caused a larger price change of demand changes. Based on the red chilli demand elasticity, if a 1 percent decrease in supply due to a decrease in production, it will cause the price to increase by 34.48 percent. The inelastic demand caused production to be critical in order to ensure the availability of red chilli supply to maintain price stability of red chilli.

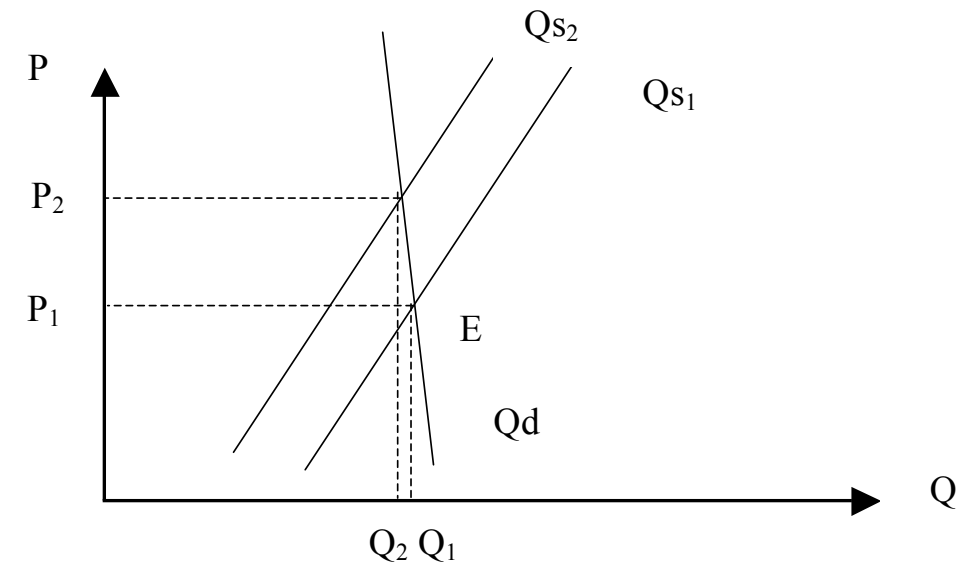

Figure 4. Movement of Red Chilli Supply Curve

The increase of fertilizer price could lead to a decrease in the amount of production that could decrease the amount of red chilli. Based on the analysis of red chilli demand and supply, the decreased number of supply could lead to high prices. If fertilizer price rises 10 percent, it could cause production to decrease by 13.26 percent, which could cause prices increase more than 100 percent. The results of this analysis indicate that 
the management of input is very important and very sensitive in maintaining the stability of production, so the policy of eliminating fertilizer subsidies should be analyzed in depth, given the demand and supply of red chlili in Indonesia is still very inelastic.

Inelastic red chili demand exacerbates the price increase when red chilli supply decreases, so in the long run it is necessary to change the consumption pattern of red chilli. The nature of the people who are more favor of fresh red chilli, can start using red chilli in the form of powder, pasta, or dried chili. In addition to increasing the added value of red chilli, also avoid falling prices at harvest time or high price increases during famine season.

In addition to input management, to maintain price stabilization through production stabilization can be done with technological improvement. The productivity of Indonesia's red chilli is still quite low, reaching only 8 tons/ha can be increased with the improvement of technology. Red chilli production increase especially when the weather is very supportive, ie when the transition weather is not too dry or not too wet, and supported by good technology, also must be managed properly so as not to cause the price dropped dramatically. The decrease in price will be felt at the farm level, therefore the need for post-harvest technology to anticipate the abundant red chilli production during the harvest. An abundant amount of production can be utilized for export or processed. Red chilli exports are generally in fresh form, but the industry that is able to absorb fresh red chilli at harvest time can also export processed chilies, in powder, paste, and dried.

The absorption of red chilli production by industry and for export, can reduce the fall of red chili price, especially at farmer level. This can reduce the price gap that occurs between the price at the producer level and the consumer level. Farmers can also be given post-harvest technology training, such as drying the red chilli to get the added value, so that can be sold to the industry at a higher price. This can also overcome market inefficiencies, as farmers can increase their knowledge and information.

The result showed that the application of the reference price policies increased the price, because of there barriers to imports of stabilizing the price, but the continuity of domestic production was not yet fully ready, pushing up prices tend to be higher. The implication of this policy was that stabilization must be able to do from within the country itself is derived from domestic production.

Prices were volatile at the retail level are not followed by a farm gate price fluctuation was not as high as the retail level. This can decrease the interest of farmers to farm red chilli. Reflected in the results of the analysis that the implementation of these policies actually reduced production. Reference pricing policy effectively decreasing the amount of imports that could not be controlled. The rates were $15 \%$ above the reference price may be considered for import. But this had not been effective in reducing price fluctuations had not been accompanied readiness for production. Reference pricing policy should be coupled with the availability of production readiness, so that it can effectively run as a means of controlling imports. Support an efficient supply chain was also required so that the gap between producer and consumer price levels were not too far away, to keep the interest of farmers.

The application of the reference price in controlling imports still more in favor of the consumer, because the increase in import prices was possible to do, but when the harvest season and the availability of excess, there was no policy that governs the price of red chilli. The reference price applied since 2013, rated yet take into account the impact received by farmers when prices were lower. The reference price was the price 
at the farm level (cost of production plus a $40 \%$ gain) multiplied by the ratio of retail price to the price the farmer during the last three years (Sayaka et al., 2014).

The application of the reference price did not significantly affect imports and prices, it showed that the reference price policy was not effective in implementation. This policy should be pursued by strengthening the development of production and encourage interest in red chilli farmers to increase the amount of production that continuity of supply remains maintained. The current agricultural development, as well as forthcoming development, directed to the development of systems and agribusiness which is competitive, populist, sustainable and decentralized (Andri and Pangarsa, 2016). Therefore, it is important to pay attention to the availability of red chili and its supply chain system, not only reducing the gap between producer and consumer levels but also maintaining the sustainability of a fair farming system.

\section{Conclusion}

The implementation of the reference price had not been effective because it was not able to manage the importation properly, causing red chilli prices were still fluctuating. Based on analysis result, the reference price applied has a positive effect which means the implementation of the policy increases the price of red chilli. Stabilization with reference price policies can be effective in improving production and importation arrangement, that means supply side of red chilli was important to stabilize red chilli price. The overall estimations showed that price of red chilli affected by supply side which consists of production, import and export. Factors positively affecting the production were land, the price of red chilli producer level, a lag of production and rainfall, while the price of subsidized fertilizer negatively. Factor positively affecting the volume of Indonesia red chilli import was lag of import volume, while the ratio of international and domestical red chilli prices negatively affecting the volume of red chilli imports. Factors negatively affecting the volume of red chilli exports was the volume of imports. Factors affecting the price of red chilli was the number of red chilli supply that had a negative effect, while the price of red chilli imports and the price of red chilli producer level had a positive effect. The red chilli demand in Indonesian society is very inelastic, so it can affect price fluctuations.in the long-term to overcome price fluctuations made by changing the pattern of red chilli consumption that does not rely on fresh red chilli. The reliance on fresh red chilli may aggravate price fluctuation, so consumption patterns should gradually shift to the consumption of dried red chilli, powders, or pastes. Answer to in an effort to stabilize the price of red chilli can be done through the planning and implementation of production improvement programs supported by input mana-gement such as planting area planning, provision of fertilizer at a stable price, also more anticipative to the impact of climate change and efficient cultivation so as to increase the productivity of red chili. 


\section{References}

Agung, I.D.G., Artini, N.W.P., Dewi, N.R. (2000). Analysis of Red Chili (Capsicum annum l) Cultivation in Perean Tengah village, Baturiti District, Tabanan. SocioEconomic of Agriculture and Agribusiness. 1:1-10. (In Indonesian)

Ali M. 2006. Chilli (Capsicum spp) Food Chain Analysis: Setting Research Priorities in Asia. The World Vegetable Center. Technical Bulletin No. 38. AVRDC Publication 06-687.

Andri, K.B., Pangarsa, N. (2016). Analyzing Determinant Components on East Java Rice Surplus Contribution Using Dynamical System Approach. International Journal of Agriculture System. 4(2): 121-131.

Anwarudin, M.J., Sayekti, A.L., Marendra A., Hilman Y. (2015). Production Dynamics and Chilli Price Volatility: Strategic Anticipation and Development Policy. Innovation Development of Agriculture. 8(1): 33-42. (In Indonesian)

Ariningsih, E., Tentamia, M.K. (2004). Supply and Demand Analysis for Shallot in Indonesia. Icaserd Working Paper. 34:1-19. (In Indonesian)

Baru, H.G., Tariningsih, D., Tamba, I.M. (2015). Farming Income Analysis Antapan Chili in The Village (A Case Study in The Village of Antapan, District Baturiti, Tabanan). Agrimeta, 5(10):14-20. (In Indonesian)

[BI] Bank Indonesia. (2017). 2016 Economic Report on Indonesia. Economic and Monetary Policy Department. Bank Indonesia. Jakarta (In Indonesian)

Chambers, M.J., Bailey, R.E. (1996). A Theory of Commodity Price Fluctuations. The Journal of Political Economy. 104(5):924-957.

Darma, R., Rahmadanih, Tenriawaru, N.A., Amandaria, R. (2014). Climate Change Adaptation in the Perspectives of Food, Energy Crisis and Environmental Degradation for Food Sovereignty in Indonesia. International Journal of Agriculture System. 2(1): 77-89.

Deaton, A., Laroque, G. (1992). On The Behaviour of Commodity Prices. Review of Economic Studies., 59:1-23.

Estrades, C., Terra, M.I. (2012). Commodity Prices, Trade, and Proverty in Uruguay. Journal Food Policy. 37(2012):58-66.

Farid, M., Subekti, N.A. (2012). Review Of Production, Consumption, Distribution and Price Dynamics of Chili in Indonesia. Buletin Ilmiah Litbang Perdagangan. 6(2):211-234. (In Indonesian)

Fitriana M. (2016). Vertical Price Transmission In Chili Market In Indonesia. thesis, Bogor Agricultural University, Bogor.

Fuller SW, Gutierrez N, Capps O Jr. 1992. International Dry Onion Trade: Factors Affecting Import Demands for US Dry Onions. Agribusiness. 8(5):445-455.

Giordani PE, Rocha N, Ruta M. 2016. Food Prices and The Multiplier Effect of Trade Policy. Journal of International Economics. 101(2016): 102-122.

Gujarati D.N. 2007. Essentials of Econometrics 2nd Edition. Mulyadi, J.A., Andri, Y (translator); Barnadi, D., Hardani, W (editor). Jakarta: Penerbit Erlangga. (In Indonesian)

Hamid, A., Haryanto, M. (2011). Hybrid Chilli Plant Cultivation for Industry. Jakarta: PT Agro Media Pustaka. (In Indonesian)

Havrila J, Gunawardana, P. 2006. Determinants of Export Supply of The Australian Textiles Exports. Journal of Economic Analysis \& Policy. 36(1):45-59.

Hoang H, Meyers W. 2015. Price Stabilization and Impacts of Trade Liberalization in The Southeast Asian Rice Market. Food Policy. 57(2015): 26-39.

Huq A.S.M.A., Arshad F.M. (2010). Technical Efficiency of Chilli Production. American Journal of Applied Sciences. 7(2):185-190. 
Indrawati, T. (2013). Analysis of Traders Behaviour in The Formation of Basic Commodities Price in Pekanbaru. Jurnal Ekonomi, 21(1), 1-9. (In Indonesian)

Jubaedah, N.S. (2013). Market Integration of Red Chilli Commodity Markets in Indonesia. thesis, International Institute of Social Studies. The Hague. Netherlands.

Kumar R, Dhawan R. 1991. Exchange Rate Volatility and Pakistani's Exports to the Developed World, 1974-85. World Development. 19(9):1225-1240.

Koutsoyiannis. 1977. Theory Of Econometrics 2nd Edition. London (UK): Macmillan Press.

Li, J.C., Chusheng, Y., Shih, W.H., Vey, W., Jiandong, W. (2013). The effect of a Target Zone on The Stabilization of Agricultural Prices And Farmers' Nominal Income. Journal of Agricultural and Resource Economics, 38(1):34-47.

Marliyana, L., Wahjoe, O. (2015). Analysis of Import Policy on Indonesia's Horticultural Products in 2012. National Seminar on Law Proceeding. 11 February 2015. 5(1), 35-45. Law Faculty, Bandung Islamic University. Indonesia. (In Indonesian)

Ministry of Agriculture. (2016). Outlook for Agricultural Commodity, Horticulture Sub-Sector: Chilli. Jakarta. Ministry Of Agriculture Republic of Indonesia. (In Indonesian)

Ministry of Commerce. (2015). Final report of food price policy analysis. Jakarta. Ministry of Commerce. (In Indonesian)

Minot, N. (2014). Food Price Volatility in Sub-Saharan Africa: Has It Really Increased?. Journal Food Policy. 45(2014): 45-56.

Mohd, Y.S., Arshad, A.M., Muhamad, N.F.H., Sidek, N.J. (2016). Potential and Viability of Chilli Cultivation Using Fertigation Technology in Malaysia. International Journal of Innovation and Applied Studies. 17(4):1114-1119.

Natale, F., Borrello, A., Motova, A. (2015). Analysis of The Determinants of International Seafood Trade Using a Gravity Model. Marine Policy. 60(2015),98106.

Nuryati Y, Farid M. 2016. Analysis of Pricing Policy Determination of Basic Needs Goods. Challenges and Directions of Indonesia's Future Agricultural Development. In the Proceedings of the National Agriculture Development, pp:193-199. (In Indonesian)

O'Brien, R.M. (2007). A Caution Regarding Rules of Thumb for Variance Inflation Factors. Quality \& Quantity. 14, 673-690.

Palar, N., Pangemanan, P.A., Tangkere, E.G. (2016). Analysis of factors Affecting Chilli Price in Manado. Agri-Sosioekonomi. 12(2): 105-120. (In Indonesian)

Parvathi, C., Arulselvam, K. (2013). A Situational Analysis of Agricultural Production and Food Security in India. Journal of Arts, Science and Commerce. 4:95-102.

Pons, N. (2011). Food and Prices in India: Impact of Rising Food Prices on Welfare. In the Proceedings of the 7th Annual Conference on Economic Growth and Development Indian Statistical Institute, pp: 1-33.

Reza, M. A. (2015). Analysis of Food Price Stabilization in Indonesia. thesis, Bogor Agricultural University, Bogor. (In Indonesian)

Saifoel, M. (2011). Analysis Of Beef Demand In Bondowoso Regency (A Dynamic Demand Of Nerlove Partial Adjustment Model) [tesis]. Jember (ID): Jember University. (In Indonesian).

Sayaka, B. Indraningsih, K.S., Iswariyadi, A., Zakaria, A.K. (2014). Analysis of Policy Report: Stabilization of Shallot and Red Chilli Price. Ministry of Agriculture. (In Indonesian) 
Schreiner M, Korn M, Stenger M, Holzgreve L, Altmann M. (2013). Current Understanding and Use of Quality Characteristics of Horticulture Products. Scientia Horticulturae. 163(2013):63-69.

Sebayang, L. (2014). Bercocok Tanam Paprika. Assessemnt Institute for Agriculture Technology, North Sumatera. Ministry of Agriculture Republic of Indonesia. (In Indonesian)

Setiawati, W., Koesandriani, Y., Hasyim, A. (2015). The contribution of curly chili kencana varieties in the face of chili self-sufficiency policy. Innovation of horticulture leverage increase in people's income. Through. http:/ / balitsa.litbang.pertanian.go.id/ind/index.php/berita-terbaru/475-bukuinovasi-hortikultura-pengungkit-peningkatan-pendapatan-rakyat.html (In Indonesian)

Sukmawati, D. (2014). The Determinant Factors of Supply That Affect Curly Red Chilli Price (Capsicum annum L.): a Case Study in Cikajang District, Garut. In the 17th International Conference And 16th Congress Of The Indonesian Society Of Agricultural Economics, pp: 50-59. (In Indonesian)

Tajdini, A., Tavakkoli, A., Latibari, A.J., Roohnia, M. (2012). The factors influencing corrugated board supply and demand in Iran: Simultaneous Equations Models. African Journal of Business Management. 6(44):10945-10951.

Tschirley, D., Snyder, J., Dolislager, M., Reardon, T., Haggblade, S., Goeb, J., Traub, L., Ejobi, F., Meyer, F. 2015. Africas's Unfolding Diet Transformation: Implication for Agrifood System Employment. Journal of Agribusiness in Developing and Emerging Economies, 5(1): 1-48.

Widarjono, A. (2016). Econometric: Introduction and Application. 4th Edition. Yogyakarta. UPP STIM YKPN. (In Indonesian)

$\mathrm{Yu}, \mathrm{X}$. (2014). Monetary Easing Policy And Long-Run Food Prices: Evidence from China. Economic Modelling 40:175-183.

Yuliadi, I. (2008). Analysis of Indonesian Import. Jurnal Ekonomi dan Studi Pembangunan, 9(1): 89-104. (In Indonesian)

Zhou, Y., Staaz, J. (2016). Projected Demand and Supply for Various Foods in West Africa: Implications for Investments and Food Policy. Journal Food Policy, 61(2016):198-212. 